\title{
ANALYSIS OF ELECTROCOAGULATION PROCESS EFFICIENCY OF COMPOST LEACHATE WITH THE FIRST ORDER KINETIC MODEL
}

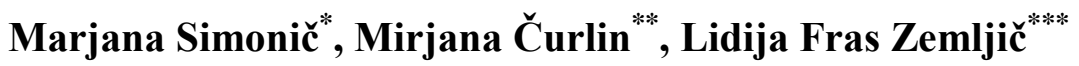 \\ * University of Maribor, Faculty of Chemistry and Chemical Engineering, Maribor, Slovenia \\ ** University of Zagreb, Faculty of Food Technology and Biotechnology, Zagreb, Croatia \\ ${ }^{* * * *}$ University of Maribor, Faculty of Mechanical Engineering, Maribor, Slovenia
}

corresponding author: Mirjana Čurlin, e-mail: mcurlin@pbf.hr

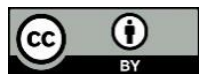

\begin{abstract}
Large quantities of leachate are generated from the water release during the decomposition of the biodegradable waste. The composition of compost leachate is very complex and its treatment is necessary before releasing into the environment. The possibilities of treating compost leachate by electrocoagulation have been extensively studied. The scope of this work was to investigate applicability of the first order kinetic model for degradation of metal and organic compounds from compost leachate by electrocoagulation process. Experimental results showed $75 \%$ removal efficiency of $\mathrm{Cu}^{2+}$ and $65 \%$ of $\mathrm{Zn}^{2+}$, while chemical oxygen demand was reduced by $36 \%$. According to obtained kinetic parameters, simulation of metal removal efficiency was performed in batch reactor. This way optimal electrocoagulation time which is needed for $95 \%$ efficiency of metal removal was determined at $120^{\text {th }}$ min for $\mathrm{Zn}^{2+}$ and $102^{\text {nd }}$ min for $\mathrm{Cu}^{2+}$.
\end{abstract}

Keywords: compost leachate, metal removal efficiency, electrocoagulation

\section{INTRODUCTION}

Compost leachate is generated during the decomposition of the biodegradable waste. The aqueous leachate cannot be released into the environment due to its hazardous nature. The composition of compost leachate is very complex and its treatment is necessary before releasing into the environment. Using the electrocoagulation (EC) process for compost leachate treatment has a lot of advantages [1]. The process is easy to operate, it is involved in simple equipment, it is offering a short retention time and it requires only a small space which contributes to low operating costs as compared to conventional ponding system or chemical coagulation. Despite being easy to operate, EC is complex technology processes which consist of three fundamental technologies: coagulation, flotation and electrochemistry. Due to the synergistic effect of different technologies, EC mechanisms that are used to remove pollution from wastewater have not yet been defined and differ for each 
wastewater. Electrocoagulation was chosen due to promising results in treating industrial waste water [1]. Using this technique there has been a little consideration of the factors that influence the effective removal of ionic species, particularly metal ions and organic matter (Chemical oxygen demand, COD) from wastewater [2]. EC reactor with aluminium or iron electrodes could also be used and the process could be optimized by varying the current, the distance between the electrodes, and electrode area and $\mathrm{pH}$ value of the treated wastewater. Successful removal, up to $95 \%$, of metal ions such as $\mathrm{Pb}^{2+}, \mathrm{Cu}^{2+}, \mathrm{Zn}^{2+}, \mathrm{Co}^{2+}$, $\mathrm{Cd}^{2+}$ and $\mathrm{Ni}^{2+}$ was achieved after $45 \mathrm{~min}$ of electrocoagulation in EC reactor with iron electrode [3]. At the distance of $1.5 \mathrm{~cm}, \mathrm{Cu}^{2+}$ was removed at $95 \%$ and $\mathrm{Zn}^{2+}$ at $80 \%$ in 60 min [4]. $99 \%$ of $\mathrm{Zn}^{2+}$ removal was achieved, while $\mathrm{Cu}^{2+}$ and $\mathrm{Ni}^{2+}$ were removed by $70 \%$ when the combination of iron and aluminium electrode was applied [5]. With a relatively low energy consumption of $0.35 \mathrm{kWh} / \mathrm{m}^{3}, 50$ $\mathrm{mg} / \mathrm{L}$ of $\mathrm{Zn}^{2+}$ was removed in $20 \mathrm{~min}$ of EC treatment [6]. COD could be removed by electrocoagulation in combination with hybrid expanded granular sludge bed and fixed-bed bioreactor [7]. It was reported that after $75 \mathrm{~min}$ at the $3 \mathrm{~cm}$ distance between aluminium electrodes at $20 \mathrm{~V}$, the COD removal reached $92 \%$.

The scope of this work was to investigate applicability of the first order kinetic model for degradation of metal and organic compounds from compost leachate by electrocoagulation process. Batch reactor with two aluminium electrodes was applied. Difference in potential enables the release of $\mathrm{Al}^{3+}$ ions from anode. Heavier suspended particles formed sludge at the bottom of reactor, while hydrogen bubbles removed volatile substances by floating to the solution surface. Nonlinear regression analysis of experimental data (at different current, electrode size, electrode distance and leachate $\mathrm{pH})$ was performed in order to determine the reaction rate constant. Dynamic simulation of EC process removal efficiency of $\mathrm{Zn}^{2+}$ and $\mathrm{Cu}^{2+}$ from leachate according to the first order kinetic model was performed.

\section{EXPERIMENTAL}

\section{Compost leachate characterization and analytical methods}

Compost leachate samples were taken from the local compost company of Kogal, Slovenia. Compost contained wetted organic matter from kitchen waste (leaves, food waste). From the compost pile, the water passed into the stabilization ponds. Compost leachate samples were taken three times during the 3 weeks from each pond. Leachate contained a lot of organic substances which were dissolved or undissolved in the solution. The main characteristics are collected and displayed in Table 1.

Table 1. Parameters of compost leachate

\begin{tabular}{|c|c|c|}
\hline Parameter & Unit & Value \\
\hline $\mathrm{pH}$ & $/$ & $5.4 \pm 0.3$ \\
\hline$\kappa$ & $\mathrm{mS} / \mathrm{cm}$ & $19-24.3$ \\
\hline $\mathrm{TSS}$ & $\mathrm{g} / \mathrm{L}$ & $20-90$ \\
\hline$\gamma\left(\mathrm{Cu}^{2+}\right)$ & $\mathrm{mg} / \mathrm{L}$ & $0.4-11$ \\
\hline$\gamma\left(\mathrm{Zn}^{2+}\right)$ & $\mathrm{mg} / \mathrm{L}$ & $6.1-20$ \\
\hline $\mathrm{COD}^{*}$ & $\mathrm{mg} / \mathrm{L}$ & $50000-80000$ \\
\hline $\mathrm{BOD}_{5}{ }^{*}$ & $\mathrm{mg} / \mathrm{L}$ & $40000-60000$ \\
\hline
\end{tabular}

* Biochemical oxygen demand

The high organic content is in range from 50 to $80 \mathrm{~g} / \mathrm{L}, \mathrm{O}_{2}$ expressed as chemical oxygen demand (COD), $\mathrm{pH}$ value was around $5.4 \pm$ 0.3 , and total suspended solids (TSS) up to 90 $\mathrm{g} / \mathrm{L}, \mathrm{Zn}^{2+}$ concentration up to $20 \mathrm{mg} / \mathrm{L}, \mathrm{Cu}^{2+}$ concentration up to $11 \mathrm{mg} / \mathrm{L}$, other metals such as $\mathrm{Cd}^{2+}, \mathrm{Ni}^{2+}, \mathrm{Cr}^{6+}$ and $\mathrm{Pb}^{2+}$ were all below 1 $\mathrm{mg} / \mathrm{L}[8]$.

Physicochemical parameters of untreated and treated compost leachate were determined. All measured parameters and standard methods are shown in Table 2. 
Table 2. Measured parameters, equipment and standard for determination physicochemical parameters

\begin{tabular}{|c|c|c|c|}
\hline Parameter & Unit & Equipment & Standard \\
\hline conductivity, $\kappa$ & $\mathrm{mS} / \mathrm{cm}$ & WTW LF537 & $\begin{array}{c}\text { SIST EN } \\
27888 \\
\end{array}$ \\
\hline $\mathrm{pH}$ & I & $\begin{array}{c}\mathrm{pH} \text { meter WTW } \\
\text { Multi } 3410\end{array}$ & $\begin{array}{c}\text { DIN } \\
38 \text { 404-C5 }\end{array}$ \\
\hline TSS & $\mathrm{mg} / \mathrm{L}$ & $\begin{array}{l}\text { Glass fibre filter, } \\
\text { oven Nabertherm }\end{array}$ & ISO 11923 \\
\hline $\mathrm{COD}$ & $\frac{\mathrm{mg} / \mathrm{L}}{\mathrm{O}_{2}}$ & $\begin{array}{l}\text { thermoreactor } \\
\text { MERCK, } \\
\text { spectroquant } \\
\text { TR 620 } \\
\end{array}$ & $\begin{array}{l}\text { SIST ISO } \\
6060\end{array}$ \\
\hline $\mathrm{BOD}_{5}$ & $\begin{array}{l}\mathrm{mg} / \mathrm{L} \\
\mathrm{O}_{2}\end{array}$ & $\begin{array}{c}\text { dilution and } \\
\text { seeding }\end{array}$ & $\begin{array}{c}\text { SIST ISO } \\
5815 \\
\end{array}$ \\
\hline$\gamma\left(\mathrm{Zn}^{2+}\right)$ & $\mathrm{mg} / \mathrm{L}$ & \begin{tabular}{|c|} 
spectrometer \\
SPECTRO \\
CIROS VISION \\
ICP-AES \\
\end{tabular} & $\begin{array}{c}\text { SIST ISO } \\
11885\end{array}$ \\
\hline$\gamma\left(\mathrm{Cu}^{2+}\right)$ & $\mathrm{mg} / \mathrm{L}$ & \begin{tabular}{|c|} 
spectrometer \\
SPECTRO \\
CIROS VISION \\
ICP-AES \\
\end{tabular} & $\begin{array}{c}\text { SIST ISO } \\
11885\end{array}$ \\
\hline
\end{tabular}

\section{EC reactor configuration}

The batch EC reactor that was applied for the treatment of the compost leachate had a total volume of $1 \mathrm{~L}$ with two aluminium electrodes immersed into the compost solution and it was connected to DC power supply. Area/volume ratio used in experiment was $15 \mathrm{~m}^{2} / \mathrm{m}^{3}$, the width of electrode was $5 \mathrm{~cm}$ and the height 12 $\mathrm{cm}$. The electrical current was measured at constant voltage. A magnetic stirrer was used to provide mixing of the solution. The scheme of the EC reactor is shown in Figure 1.

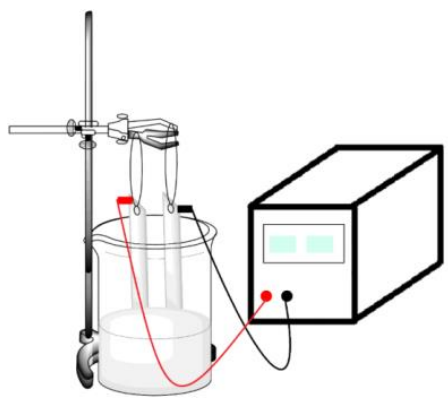

Figure 1. Scheme of electrocoagulation batch reactor (DC power and reactor with electrodes)

The main reaction occurring at the aluminium anode is dissolution [9]:

$$
\mathrm{Al}_{(\mathrm{s})} \rightarrow \mathrm{Al}^{3+}+3 \mathrm{e}^{-}
$$

Additionally, water electrolysis occurs at the cathode and anode:

$2 \mathrm{H}_{2} \mathrm{O}+2 \mathrm{e}^{-} \rightarrow \mathrm{H}_{2(\mathrm{~g})}+2 \mathrm{OH}^{-}$(cathodic reaction)

$2 \mathrm{H}_{2} \mathrm{O} \rightarrow 4 \mathrm{H}^{+}+\mathrm{O}_{2(\mathrm{~g})}+4 \mathrm{e}^{-}$(anodic reaction)

A direct electrochemical reduction of metal cations $\left(\mathrm{Me}^{\mathrm{n}+}\right)$ may occur at the cathode surface:

$$
\mathrm{Me}^{\mathrm{n}+}+\mathrm{ne}^{-} \rightarrow \mathrm{nMe}^{0}
$$

In addition, anodic metal ions and hydroxide ions generated at the electrode surfaces react in the bulk wastewater to form various hydroxides and built up polymers:

$$
\begin{gathered}
\mathrm{Al}^{3+}+3 \mathrm{OH}^{-} \rightarrow \mathrm{Al}(\mathrm{OH})_{3(\mathrm{~s})} \\
\mathrm{n} \mathrm{Al}(\mathrm{OH})_{3(\mathrm{~s})} \rightarrow \mathrm{Al}_{\mathrm{n}}(\mathrm{OH})_{3 \mathrm{n}(\mathrm{s})}
\end{gathered}
$$

Al species are capable of removing organic compounds, while equation 5 is mostly adequate for metal removal [9].

Removal efficiency $(\eta)$ of metal ions $\left(\mathrm{Zn}^{2+}\right.$, $\mathrm{Cu}^{2+}$ ) and COD was calculated according to equation 6 :

$$
\eta=\frac{\gamma_{0}-\gamma_{1}}{\gamma_{0}} \cdot 100 \%
$$

where is: $\eta$ - removal efficiency $(\%), \gamma_{0}$ - initial concentration (ions) (mg/L), $\gamma_{1}$ - final concentration (ions) $(\mathrm{mg} / \mathrm{L})$.

\section{Kinetic model}

Nonlinear regression analysis was used to describe the $\mathrm{Zn}^{2+}$ and $\mathrm{Cu}^{2+}$ removal in the EC process. The first order kinetic model has been used to simulate experimental data [10]:

$$
\frac{\mathrm{d} \gamma}{\mathrm{d} t}=k \cdot \gamma
$$


Kinetic parameters $k$ for both ions were determined from EC experiments with different current and different initial concentration of $\mathrm{Zn}$ and $\mathrm{Cu}$ ions. Based on the obtained kinetic parameters, simulation of removal efficiency was performed according to the first order kinetic model in the batch reactor. This model in nondimensional form is shown in equation 8 :

$$
\frac{\mathrm{d} \eta}{\mathrm{d} \tau}=1-\eta
$$

where is: $\tau$ - non-dimensional time for batch reactor $(k \cdot t)$.

In order to compare the first and second order kinetic models, the same procedure was performed for second order kinetic model in batch reactor according to equation 9:

$$
\frac{\mathrm{d} \eta}{\mathrm{d} \tau}=(1-\eta)^{2}
$$

Taking into consideration the initial condition $\eta(t=0)=0$, removal efficiency function was obtained by using W.R. Mathematica software. The time for $95 \%$ removal efficiency was determined for both ions.

\section{RESULTS AND DISCUSSION}

The batch EC reactor was filled with brown coloured leachate that changed its colour during the electrocoagulation process. Conductivity, $\mathrm{pH}$ and current were measured during $60 \mathrm{~min}$ of electrocoagulation with aluminium electrodes. The results of measurements are presented in Table 3. The voltage $15 \mathrm{~V}$ was applied which was higher than reported [6] when model solutions were treated, but lower as $20 \mathrm{~V}$ in case of organic pollutants removal from high strength wastewater [7]. Even though the model solutions suggested the removal of only metals, the aim of our study was to decrease the content of organic compounds expressed as COD, which was huge, determined at $85.4 \mathrm{~g} / \mathrm{L}$ $\mathrm{O}_{2}$. The main share of electric energy consumption was due to organic colloids removal. The initial $\mathrm{pH}$ value was 5.4 which means that monomeric Al-species such as $\mathrm{Al}^{3+}, \mathrm{Al}(\mathrm{OH})^{2+}$ and $\mathrm{Al}(\mathrm{OH})_{2}{ }^{+}$are present in the solution. Organic compounds adsorbed on Al-species to form flocs and settle to the bottom as precipitate. Current increased at first from $1.3 \mathrm{~A}$ to approximately $2.0 \mathrm{~A}$ after 30 min and then stabilized at $2.17 \mathrm{~A}$. It is assumed that organic substances hindered electricity transfer between electrodes and due to this resistance temperature also increased for $5{ }^{\circ} \mathrm{C}$. As metals were removed, more $\mathrm{OH}^{-}$ ions remained in bulk solution and therefore $\mathrm{pH}$ increased in accordance with another study [6].

Table 3. Measurements of conductivity, $\mathrm{pH}$ and current in time dependence

\begin{tabular}{|c|c|c|c|}
\hline$t / \mathrm{min}$ & $\kappa / \mathrm{mS} / \mathrm{cm}$ & $\mathrm{pH}$ & $\mathrm{I} / \mathrm{A}$ \\
\hline 0 & 22.0 & 5.4 & 1.32 \\
\hline 5 & 22.2 & 5.5 & 1.54 \\
\hline 10 & 22.4 & 5.6 & 1.68 \\
\hline 15 & 22.6 & 5.6 & 1.85 \\
\hline 20 & 22.7 & 5.7 & 1.93 \\
\hline 25 & 22.7 & 5.7 & 1.98 \\
\hline 30 & 22.8 & 5.7 & 2.04 \\
\hline 35 & 22.9 & 5.8 & 2.10 \\
\hline 40 & 22.9 & 5.8 & 2.13 \\
\hline 45 & 23.0 & 5.8 & 2.17 \\
\hline 60 & 23.0 & 5.8 & 2.17 \\
\hline
\end{tabular}

During electrocoagulation, a lot of foam was formed, as shown in Figure 2. It was removed physically with a spoon.

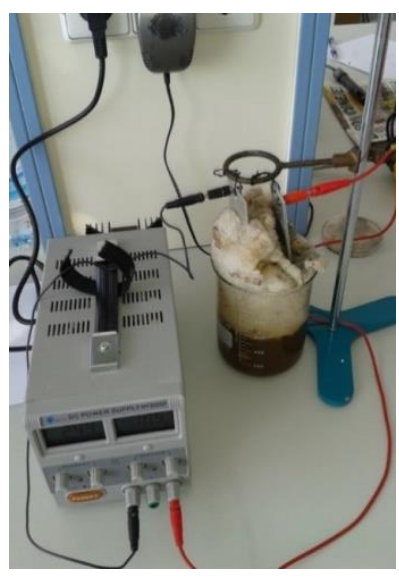

Figure 2. Foam formed during electrocoagulation 
Initial sample contained $8.1 \mathrm{mg} / \mathrm{L} \mathrm{Zn}^{2+}$ and 4.3 $\mathrm{mg} / \mathrm{L} \mathrm{Cu}^{2+}$. Samples were taken after 20,40 and $60 \mathrm{~min}$ of electrocoagulation and the concentrations of metals were determined at 4.5, 3.1 and $2.8 \mathrm{mg} / \mathrm{L} \mathrm{Zn}^{2+}$ and $1.8,1.0$ and 0.8

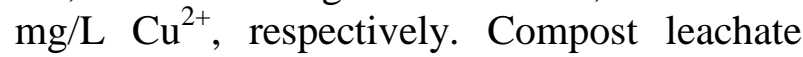
contained a lot of organic compounds, which could hinder the adsorption capability of $\mathrm{Al}^{3+}$ ions which were released from anode into the leachate by adhering on $\mathrm{Al}^{3+}$. From $85.4 \mathrm{~g} / \mathrm{L}$ $\mathrm{O}_{2}$ the COD was reduced after one hour of electrocoagulation down to $54.6 \mathrm{~g} / \mathrm{L} \mathrm{O}_{2}$. The efficiency was only $36 \%$. BOD reduction was practically the same $(35 \%)$. A share of organic compound was removed by the gas bubbles, while a lot of foam was formed. It had to be physically removed. Figure 3 shows leachate at the beginning, after one hour of electrocoagulation treatment and the third one after 1 hour of EC and one hour of settling. It is seen that the settling time was very important regarding suspended solids removal. It was assumed that $\mathrm{Zn}^{2+}$ and $\mathrm{Cu}^{2+}$ were removed according to reactions expressed in equation (5) and also as precipitate in form of $\mathrm{Zn}(\mathrm{OH})_{2}$ and $\mathrm{Cu}(\mathrm{OH})_{2}$. Since a lot of organic compounds did not settle and remained in the solution, it is assumed that also complexes were formed between organic compounds and metals which remain in the solution.

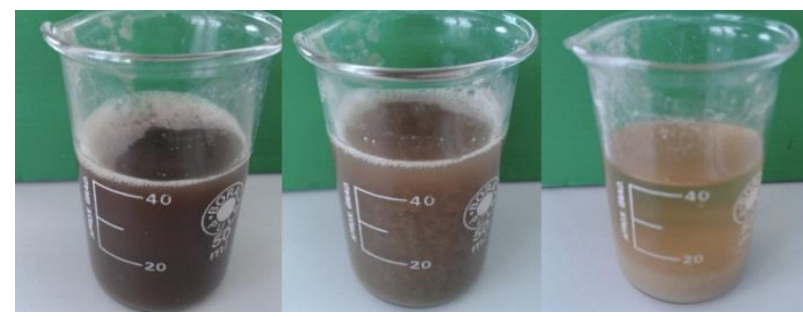

Figure 3. Changing of compost leachate during electrocoagulation in dependence of time (left at the beginning, in the middle after 1 hour of EC and right after 1 hour of EC and 1 hour of settling)

Nonlinear regression analysis of experimental data of EC process with different current and initial concentration of both ions was performed in order to determine the reaction rate constant. Kinetic parameter $k_{\mathrm{Zn}}$ was $0.0256 \mathrm{~min}^{-1}$ and $k_{\mathrm{Cu}}$ was $0.0292 \mathrm{~min}^{-1}$. According to the obtained kinetic parameters, simulation of removal efficiency was performed (equation (8) and (9)) and time for $95 \%$ removal efficiency was determined for both ions. Results of the first order kinetic model showed that $95 \%$ heavy metal removal efficiency could be achieved in the $120^{\text {th }} \mathrm{min}$ for $\mathrm{Zn}^{2+}$ and in the $102^{\mathrm{nd}}$ min for $\mathrm{Cu}^{2+}$. Results of simulation removal efficiency according to the first and second order kinetic model for batch reactor and EC experimental results are shown in Figure $4\left(\mathrm{Zn}^{2+}\right)$ and Figure $5\left(\mathrm{Cu}^{2+}\right)$.

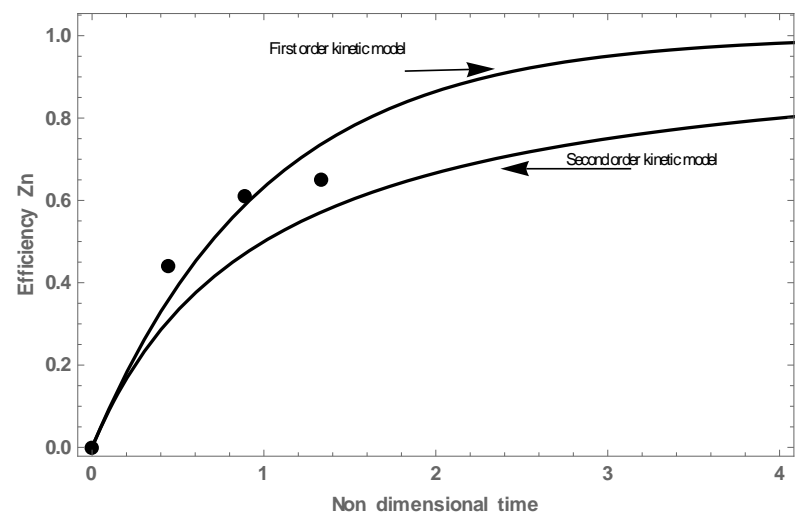

Figure 4. EC experimental results of removal efficiency (points) as well as the first and the second order kinetic model of removal efficiency (line) for $\mathrm{Zn}^{2+}$ ion

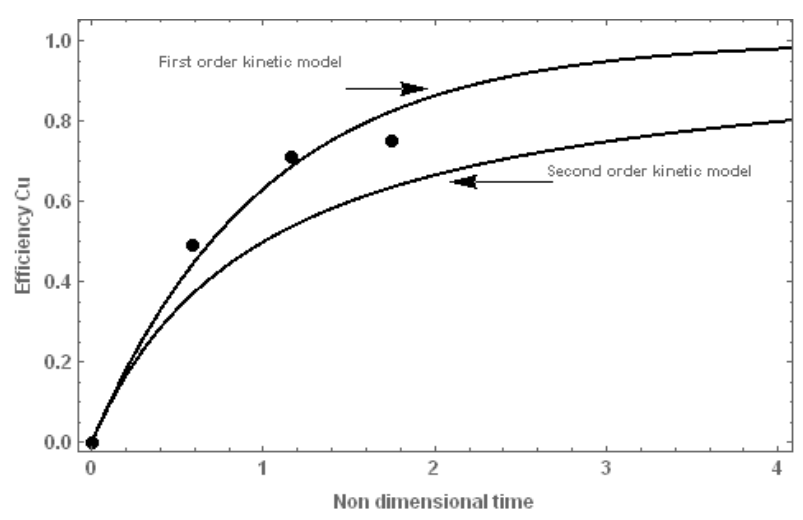

Figure 5. EC experimental results of removal efficiency (points) as well as the first and the second order kinetic model of removal efficiency for $\mathrm{Cu}^{2+}$ ion

The two-hour electrocoagulation was previously reported as optimal [7], therefore the results of present study are in accordance with the references. The obtained experimental results of $\mathrm{EC}$ process for $\mathrm{Zn}^{2+}$ and $\mathrm{Cu}^{2+}$ ions can be described with the first order kinetic model for batch reactor. 


\section{CONCLUSION}

EC with $\mathrm{Al}$ electrodes was performed in order to remove metals and organic compounds from compost leachate. The results showed that $\mathrm{Cu}^{2+}$ and $\mathrm{Zn}^{2+}$ were efficiently removed from compost leachate using electrocoagulation. The results of experiments were attained with a 60 min electrocoagulation at $\mathrm{U}=15 \mathrm{~V}, \mathrm{r}=3$ $\mathrm{cm}$ and initial $\mathrm{pH} \mathrm{5.4,} \mathrm{where} \mathrm{the} \mathrm{removal}$ efficiency of $\mathrm{Cu}^{2+}$ was $75 \%$, and $\mathrm{Zn}^{2+} 65 \%$. The organic compound (COD and BOD) of compost leachate was reduced by $36 \%$ and 35 $\%$ respectively. Results of the first order kinetic model showed that $95 \%$ heavy metal removal efficiency could be achieved in $120^{\text {th }}$ min for $\mathrm{Zn}^{2+}$ and $102^{\text {nd }}$ min for $\mathrm{Cu}^{2+}$. Obtained experimental results of EC process for $\mathrm{Zn}{ }^{2+}$ and $\mathrm{Cu}^{2+}$ can be described with the first order kinetic model for batch reactor.

\section{REFERENCES}

[1] E. Gatsios, N.J. Hahladakis, E. Gidarakos, Optimization of electrocoagulation (EC) process for the purification of a real industrial wastewater from toxic metals, Journal of Environmental Management 154(2015), 117-127.

[2] M.A.M. Yousuf, R. Schennach, J.R. Parga, D.L. Cocke, Electrocoagulation (EC) - science and applications, Journal of Hazardous Materials 84(2001) 1, 2941.

[3] M. Al-Shannag, Z. Al-Qodah, K. BaniMelhem, M. Rasool Qtaishat, M. Alkasrawi, Heavy metal ions removal from metal plating wastewater using electrocoagulation: Kinetic study and process performance, Chemical Engineering Journal 260(2015), 749756.

[4] M. Prica, S. Adamovic, B. Dalmacija, L. Rajic, J. Trickovic, S. Rapajic, M. Becelic-Tomin, The electrocoagulation /flotation study: The removal of heavy metals from the waste fountain solution,
Process Safety Environmental Protection 94(2015), 262-273.

[5] J.G. Rincón, J.E. La Motta, Simultaneous removal of oil and grease, and heavy metals from artificial bilge water using electro-coagulation/flotation, Journal of Environmental Management 144(2014), 42-50.

[6] X. Chen, P. Ren, T. Li, J.P. Trembly, X. Liu, Zinc removal from model wastewater by electrocoagulation: Processing, kinetics and mechanism, Chemical Engineering Journal 349(2018), 358-367.

[7] W. Dastyar, T. Amani, S. Elyasi, Investigation of affecting parameters on treating high-strength compost leachate in a hybrid EGSB and fixed-bed reactor followed by electrocoagulation-flotation process, Process Safety and Environmental Protection 95(2015), 111.

[8] M. Simonic, J. Volmajer Valh, S. Vajnhandl, S. Hribernik, M. Kurecic. L. Fras Zemljic, Alternative cleaning of compost leachate using biopolymer chitosan, Fibres and Polymers 18(2017) 2, 445-452.

[9] I. Heidmann, W. Calmano, Removal of $\mathrm{Zn}$ (II), $\mathrm{Cu}(\mathrm{II}), \mathrm{Ag}(\mathrm{II}), \mathrm{Ni}(\mathrm{II}), \mathrm{Cr}(\mathrm{VI})$ present in aqueous solution by aluminium electrocoagulation, Journal of Hazardous Materials 152(2008) 3, 934941.

[10] J.N. Hakizimana, B. Gourich, M. Chafi, Y. Stiriba, C. Vial, P. Drogui, J. Naja, Electrocoagulation process in water treatment: A review of electrocoagulation modeling approaches, Desalination 404(2007), 1-21. 